\title{
Slipping on Banana Skins and Falling Through Bars: "True" Comedy and the Comic Character
}

\section{Jack Black}

Sheffield Hallam University. Sheffield, UK. Email: j.black[at]shu.ac.uk

\section{Abstract}

From Basil Fawlty, The Little Tramp and Frank Spencer; to Jim Carey, Andy Kaufman and Rowan Atkinson... comedy characters and comic actors have proved useful lenses for exploring and exposing - humor's cultural and political significance. Both performing as well as chastising cultural values, ideas and beliefs, the comic character gives a unique insight into latent forms of social exclusion that, in many instances, can only ever be approached through the comic form. It is in examining this comic form that this paper will consider how the 'comedy character' presents a unique, subversive significance. Drawing from Lacanian conceptions of the subject and television 'sitcom' examples, the emancipatory potential of the comedy character will be used to criticize the predominance of irony and satire in comic displays. Indeed, while funny, it will be argued that such comic examples underscore a deprivative cynicism within comedy and humor. Countering this, it will be argued that a Lacanian conception of the subject can profer a comic efficacy that not only reveals how our social orders are inherently inconsistent and open to subversive redefinition, but that these very inconsistencies are also echoed in the subject, and, in particular, the 'true comedy character'.

\section{Keywords}

Subject; Zupančič; Žižek; Lacan; Concrete Universal; Subversion; The Real; Satire; Cynicism; Irony

This work is licensed under a Creative Commons «Attribution» 4.0 International License 


\section{Поскользнуться на банановой кожуре и провалиться сквозь барную стойку: «настоящая» комедия и комический персонаж}

\section{Блэк Джек}

Университет Шеффилд-Халлам. Шеффилд, Великобритания. Email: j.black[at]shu.ac.uk

\section{Аннотация}

От Бэзила Фолти, Маленького Бродяги и Фрэнка Спенсера к Джиму Кэри, Энди Кауфману и Роуэну Аткинсону... комедийные персонажи и комические актеры послужили увеличительными стеклами для успешного исследования и выявления культурного и политического значения юмора. Комический персонаж, изображая, а также и критикуя культурные ценности, идеи и убеждения, уникально выявляет латентные формы социального отстранения, к которым во многих случаях можно приблизиться только через комическую форму. Именно в ходе изучения этой комической формы в данной статье будет рассмотрено, каким образом «комедийный персонаж» репрезентирует уникальную, субверсивную (разрушительную) значимость. Освободительный потенциал комедийного персонажа будет применен, с опорой на концепцию субъекта Ж. Лакана и примеры телевизионных «ситкомов», для критики преобладания иронии и сатиры в явлениях комического. В самом деле, хотя такие комические примеры забавны, здесь будет доказываться, что они усиливают депривационный цинизм комедии и юмора. В противовес этому утверждается, что лакановская концепция субъекта может предложить такой комический эффект, который не только раскрывает, в какой мере наши социальные порядки по своей природе непоследовательны и открыты для революционного переопределения, но и что сами эти несоответствия также отражаются в субъекте и, в частности, в «настоящем комедийном персонаже».

\section{Ключевые слова}

субъект; Зупанчич; Жижек; Лакан; конкретно-всеобщее; субверсия; Реальное; сатира; цинизм; ирония

Это произведение доступно по дицензии Creative Commons «Attribution» («Атрибуция») 4.0 Всемирная 


\section{Introduction}

Comedy remains a useful tool for exposing the nullity and averring the absurdity in what we would otherwise consider to be the mundane triviality of a variety of day-to-day social interactions and norms. The comic character, in particular, proves indicative of a certain 'ridiculousness'. From Mr. Bean (Rowan Atkinson) to Basil Fawlty (John Cleese); from Homer Simpson (Dan Castellaneta) to Carlton Banks (Alfonso Ribeiro), the comic character epitomises the very personal flaws and social weaknesses that beleaguer the human. What is more, these faults, shortcomings and comic failures are not simply held by the comic 'character'-as merely a personal characteristic, unique to the character's biography-but can also help to expose the strange practices and inexplicable oddities that, while often taken for granted, nonetheless reveal the very social ambiguities and cultural distinctions of being human.

Nowhere is this more apparent than in the various comic performances of Sacha Baron Cohen. Mixing comedy with method acting, Cohen's 'Ali G, 'Borat' and 'Bruno' personas seek to dissolve the line between 'journalism' and comedy, with each character using the transgressive to lay bare the inherent contradictions of contemporary public debates (Alonso, 2016). Here, Cohen frequently engages with the 'general public' in order to induce an open acknowledgement of one's racism, homophobia or sexism.

Though Cohen's performances can be read as exposing a certain perversion in their desire to identify, expose and ridicule the hidden transgressions that undergird our social norms and 'polite' conventions, more traditional fictional forms, such as the comedy film or television sitcom ('situated comedy'), are steered by comic characters, who, in their fictional realities, help to comically perform a number of cultural tropes and social faux-pas. The previously mentioned Mr. Bean and Basil Fawlty prove notable.

These characters, however, present a significant paradox. For Alenka Zupančič, comedy's materialism-that is, its capacity to effectively render our 'human limitations and deficiencies'-is undermined by the fact that:

Regardless of all accidents and catastrophes (physical as well as psychic the concrete universal or emotional) that befall comic characters, they always rise from the chaos perfectly intact, and relentlessly go on pursuing their goals, chasing their dreams, or simply being themselves. It seems that nothing can really get to them, which somehow contradicts the realistic view of the world that comedy is supposed to promote. $(2008$, pp. $28-29)$

Such relentless perseverance is aptly demonstrated in the following example from Zupančič: 
a toffee-nosed baron slips on a banana peel (thus demonstrating that even he is subject to the laws of gravity), yet the next instant he is up again and walking around arrogantly, no less sure of the highness of His Highness, until the next accident that will again try to 'ground' him, and so on and so on. (Take, for example, Sir John Falstaff in Shakespeare's comedy The Merry Wives of Winsdor) (2008, p. 29)

Zupančičs claim helps to lay bare the importance that can be afforded to the comedy character and its capacity to expose and critique contemporary social conventions as well as contentious forms of humour, such as racist and sexist jokes (Black, 2021). To draw out this significance, we must first consider and critique the contemporary prevalence of 'false' forms of comedy, such as satire, cynicism and irony.

\section{True and false comedy}

In their critique of Cohen's performances in his Da Ali G Show (2000-2004), Paul Alonso highlights how:

The 'journalistic' component of Baron Cohen's characters becomes an initial (but essential) departure to developing a more complex structural critique. Connecting Sacha Baron Cohen's satire with theories of carnival, spectacle, and infotainment offers insight into the important role that satire plays in today's public debates. (2016, p. 584).

Cohen's performances walk a line between openly avowing the very contentions he wishes to subvert and, as evident in the above quotation, openly performing these very contentions in a way that steers more towards a perverse endorsement, which enjoys the performance of the taboo just as much as it does ridiculing them. In fact, this contradiction, it is argued, has become a formative feature of comedy's postmodern condition, so that, 'Through parody, irony, and selfreflexivity, postmodernism is able to both legitimize and subvert culture (both high culture and mass culture) at the same time' (Flisfeder, 2017, pp. 73-74).

Indeed, these contradictions have underscored work that has sought to analyse the performance of racist jokes and comedy sketches (Billig, 2001; Weaver, 2011). As noted by Flisfeder (2017), in many instances the contradiction lies between the legitimization of certain forms of humour-as evident in the performance itself-and the potential subversion that can arise when one openly performs this humour (Black, 2021). This contradiction can be approached by considering whether the comic performance, and the audience's relation to this performance, requires us to 'laugh with' the performance or 'laugh at' the performance (Peters \& Becker, 2010). Too often, examples of cynicism, irony and satire follow the latter and, as a result, the audience remains safely distanced from the performed comedy.

Certainly, such appraisals may seem largely positive, especially when one considers how comedy can, in the case of the comic character, render our humanness palpable, reminding us all that we are 'only human' (Critchley, 2002). However, Zupančič's claim is to defer from any such appraisal. As an example of 'false comedy', 
we can attribute instances of cynicism, satire and irony to a conservatism that ultimately maintains the status quo, and, thus, emphatically fails to dilute any subversive intention. Consequently, it is in the form of 'false comedy' that 'comedy gets turned into a drab lesson meant to show us our mere humanity-to teach us that we are not perfect, that after all we are only human, that we should simply accept our weaknesses, limitations and imperfections' (Kottman, 2008, p. 4).

To help illustrate this significance, Zupančič draws upon the former U.S. President, George W. Bush, who would deliberately 'mock his own presidential self', so that while such mocking, in most instances, comically 'portray[ed] the inflexible war President as "the guy next door" fully 'aware of his faults and imperfections' (2008, p. 33), these gestures ultimately served to distance Bush from his own (real) concreteness. That is, the distance between Bush-the self-depreciating man (concrete)-and Bush-the President of the United States, head of state, head of government and commander-in-chief of the U.S. Armed Forces (universal)-was constituted in a media strategy that benefitted Bush through his comic 'human' failings.

These false comedy gestures serve to maintain one's symbolic authority, as seen in 'the White House Correspondents' Dinner, a banquet where authority openly mocks itself' (McGowan, 2014, p. 208). The dinner is notable for offering the U.S. President a light-hearted opportunity to mock both himself, his office and the Presidential cabinet. The effect of this open mockery, however, is that it never confronts the President's symbolic authority; instead, by satirising the role, the President maintains this very position through a satirical self-distancing.

The point to be made here is that it is in examples of cynicism, satire and irony -conceived in the above instances as examples of false comedy-that there remains a distance between the universal and concrete. Accordingly:

\footnotetext{
The paradigm of these [false] comedies is simply the following: the aristocrat (or king, or judge, or priest, or any other character of symbolic stature) is also a man (who snores, farts, slips, and is subject to the same physical laws as other mortals). The emphasis is, of course, precisely on 'also': the concrete and the universal coexist, the concrete being the indispensable grounding of the universal. (Zupančič, 2008, p. 30)
}

We can observe examples of this in Ricky Gervais and Stephen Merchant's Extras (2005-2007). Through the show's portrayal of 'real' celebrities, as 'surreal, bizarre, and sometimes even tyrannical' (McKenna, 2015, p. 205), Gervais and Merchant were able to position a number of well-known actors, musicians and television personalities in situations that allowed them to perform exaggerated versions of themselves. In one notable scene from series two, episode four ('Chris Martin', 2006), we watch the show's lead character, Andy Millman (Ricky Gervais), filming a charity appeal advert. After filming his short segment, Chris Martin, lead singer of the band Coldplay, enters the room to film a similar segment. Upon speaking to one of the directors it becomes clear that Martin is only interested in promoting Coldplay's new album, a greatest hits compilation. Subsequently, he asks if the backdrop 
could contain an image of the new album; he suggests that perhaps Coldplay's music could accompany the advert; and, when told that neither of these suggestions would be possible, he turns to the camera and unbuttons his coat in order to reveal a picture of Coldplay's (fictional) greatest hits album printed on his t-shirt-the words 'out now' clearly visible. The scene is certainly funny, with the segment playing off the fact that, rather than genuinely wishing to help the charity's benefactors, Martin is instead using the opportunity to promote his own music.

Indeed, what becomes evident in the Martin scene is the way in which a famous celebrity performs a comic version of themself, in much the same way that certain politicians perform their 'comic' self. In the case of Martin, we have 'Chris Martin', the real musician, and 'Chris Martin', the exaggerated comic persona. The scene's comedy relies upon him representing a comic persona that maintains a clear separation between the 'real' Chris Martin and the 'fake' Chris Martin. In fact, once completed, the real Chris Martin can walk off set, safe in the knowledge that his 'satirical' performance leaves the 'real' subject intact (even Chris Martin can have a laugh at himself).

Therefore, what becomes clear in the above is the extent to which, while submitting figures of authority to ridicule, ultimately, such practices maintain their power. In false comedy 'it is the logic of domination that is allowed to operate freely, not in spite but because of efforts to undermine it' (Bonic, 2011, p. 97).

In contrast to 'false comedy' examples, Zupančič relies upon her unique adoption of the Hegelian concrete universal as a fundamental feature of 'true' comic expression. Indeed, for Zupančič, 'the comic character is defined by a particular integration of a universal in a concrete individuality' (Ladegaard, 2014, p. 116). As a result, true comedy occurs when the universal, in both its abstract and actual dimensions, is brought together in a particular concrete example that provides a short circuit (a change of places) between the universal and particular. With regard to Zupančič's example of the baron who slips on a banana peel, the comedy of this scene is not drawn from the fact that anyone-even a baron-can slip on a banana peel, but, instead, it is when the baron stands up and presumptuously continues to appear to himself as a 'baron' that true comedy is performed. It is the symbolic title, 'baron', which proves comic.'

\section{Comic subjectivity}

For a true comic character, there remains no distance between the comic actor and performed persona, but, rather, it is in the form of comedy that the comic

1 Drawing upon a popular Lacanian example, Zupančič notes: 'The point is not that an aristocrat is also an ordinary man. He is an ordinary man precisely as an aristocrat, at the very peak of his aristocracy. Here we should recall Lacan's famous remark that a lunatic is not some poor chap who believes that he is a king; a lunatic is a king who believes that he really is a king. Does this not hold even more for comedy? It is not some poor chap who believes himself to be a king who is comical (this is rather pathetic), but a king who believes that he really is a king' (2008, p. 32). 
actor immanently embodies the comic character (Žižek, 2005). In other words, the true comic character is 'not so much involved in unveiling and disclosing the nudity or emptiness behind appearances as [it is] involved in constructing emptiness (or nudity)' (Zupančič, 2003, pp. 166-167). The import behind this construction is that the comic character is, in its most subversive form, not merely there to simply reveal that all our social norms and values are defunct, but that it is in the true comic character that 'The comic work takes the hero's position seriously, accepts it, and follows it to the point where it reveals its own absurdity and so destroys itself' (Roche, 2002, p. 415). Here, the inconsistencies of the universal are repeatedly performed in the comic persona (Donougho, 2016), 'expos[ing] the fundamental incongruity between men and their fantasies in all its concrete materiality' (Ladegaard, 2017, p. 183).

Accordingly, as an adjunct to Zupančičs (2008) baron example, the well-known 'Del falls through a bar' scene from the British comedy Only Fools and Horses (19812003), allows us to see how 'the ebullient, ever cheeky Derek "Del Boy" Trotter', a comic character 'always with a new joke on the tongue and a new girl on his arm' (McKenna, 2015, p. 200), avails a presumptuous authority that is analogous to the baron who believes he is a baron. In fact, much like the baron, there is not much to confirm Del's (David Jason) image, apart from his excessive attempts to belong to a symbolic order which confers such authority.

This is emphasised when we consider that the series was set during 1980s Thatcherism, and, though the social context was rarely acknowledged, 'the rise of the yuppie and the struggle of working class communities to scrimp and scrape in face of the neo-liberal onslaught' (McKenna, 2015, p. 200) was a narrative that proved salient in the show's storylines and its lead characters: Del Boy and Rodney Trotter (Nicholas Lyndhurst). It is against this context that, rather than be excluded from this world, Del seeks to be a part of it, and it is in this way that Del's comic performances work to highlight the inherent inconsistences and modes of excess of the period. In fact, McKenna notes that Del is often seen in 'red braces, gaudy gold chains and yuppie Filofax' (2015, p. 200), an amalgamation of the 1980s 'loadsamoney/yuppie' aesthetic. Moreover, Del is a character who, despite his Londonworking class background, desperately seeks to be viewed as an intelligent entrepreneur, adept at the art of business, widely admired by women and respected by men. Throughout the show's series he dreams up and concocts various schemes to 'make money', with the added surety of his own entrepreneurial abilities. Indeed, Del's unbridled confidence is often contrasted against his less-sure younger brother, Rodney. Notably, however, it is in the famous bar scene that we witness Del's presumptuous attitude concretely performed.

In the scene, Del stands at the end of a bar with his friend Trigger (Roger Lloyd Pack), with Del explaining to Trigger the type of 'man' that women 'go for'. In an attempt to prove his mature sophistication, and 'natural' ability to charm the opposite sex, Del seeks to attract the attention of one of the many 
women who are in the bar. With one arm on the bar, Del looks out across the room and catches the eye of an attractive woman, who gives him a certain look. Taking a breath, Del lifts his arm from the bar, stands straight and says to Trigger: 'We're on a winner here, Trig. Alright, play it nice and cool son, nice and cool, you know what I mean...' Unawares to Del and Trigger, a waiter has just left the bar via the flip-up counter-top which Del had previously had his arm resting on. As he finishes speaking to Trigger, he leans back against the counter-top which is now raised. With drink in hand, Del falls through the gap in the bar. In a continuation of the scene's comic performance, Trigger, who is much taller than Del, fails to notice the fall and does a full-circle to see where Del has gone (adding to the scene's comedy, he fails to look 'down' where he would clearly see Del on the floor of the bar). While Trigger spins around, shocked at Del's sudden disappearance, Del jumps up off the floor, dishevelled and wet from his spilt drink. With a 'cool' nonchalant shrug of the shoulders, Del re-establishes his composure and leaves the bar, all the while maintaining his self-assurance.

Here, Del's symbolic identity-a confident, charming, suave 'ladies' man'is concretely performed in his sudden comic fall. Again, much like Zupančičs (2008) baron, this example is not significant for the fact that anybody could, while attempting to impress, fall through a bar, slip down a manhole, or slide on a banana skin-examples that would all give the impression that Del is just like anybody else-but rather it is the manner in which Del quickly asserts his assumed symbolic status that proves truly comical. In this particular scene, it is Del's universal impotence which is comical.

What bears further significance, however, is how the comic character stands apart to other dramatic forms, such as tragedy. For example, in most tragic performances, our ability to believe the performance of the actor-their representation of a particular persona-is tied to the quality of the actor-subject's performance of the fictional character (think of well-known and widely lauded performances such as Robert De Niro as Travis Bickle in Taxi Driver [1976], or Marlon Brando as Colonel Kurtz in Apocalypse Now [1979]). In dramatic forms such as tragedy, what we see is:

an organic fusion or synthesis of the actor-subject and the character precisely because the subject represents the character (and the better the representation, the more powerful will be the feeling of a fusion of these two, of the individual and the universal). (Zupančič, 2008, p. 35).

Central to Zupančič's account is that such performances are 'a fusion of ... two', with the credited actor performing the universal (the 'tragic' character). In so doing, the actor (concrete) and the universal are brought together through a fused coincidence, with the actor's performance measured by their ability to represent ('perform') the universal. ${ }^{1}$

1 It is this formal structure which is reflected in instances of false comedy and in those politicians who 'imitate' or represent their own comic selves (Zupančič, 2008). In the UK, one is reminded of politicians, such as the current U.K. Prime Minister, Boris Johnson, whose comic persona and various gaffes have proven a formative feature of his political persona. 
Certainly, the distinction being drawn in the above example is not one in which the 'comic performance' is ignored, but that rather than simply representing a certain 'character', the comic character is this representation. It is on this basis that 'The comic thus appears to be inscribed into the very kernel of subjectivity' (Ruda, 2016, p. 169). In fact, 'by emphasizing the necessity of contingency and the contingency of necessity at the ground of subjectivity' (Ruda, 2016, p. 170), the comic character helps to expose the ontological inconsistency which underscores our social identities and universal notions, including the subject itself. Notably, we see this inconsistency performed when a character contingently embodies a symbolically constructed and universally defined notion (a 'King', 'priest', 'judge', 'President'): an incongruity which lays bare the 'gap' in their symbolic investment and their actual, concrete, material embodiment.

This 'gap' can help elucidate the relationship between the subject and comedy. It is in the comedy character that the inherent contradictions, antagonisms and impasses of the social order are concretely performed. In other words, the comic character is not just a representation of a particular 'fictional' persona, but a performance of the (Lacanian) divided subject-of the subject as Real. Here, Žižek details how such division reveals the 'gap' inherent to the subject, the 'same gap [which] is also exemplified by the two names of the same person':

The pope is at the same time Karol Wojtyla and John Paul II: the first name stands for the 'real' person, while the second name designates this same person as the 'infallible' embodiment of the Institution of Church-while the poor Karol can get drunk and babble stupidities, when John Paul speaks, it is the divine spirit itself which speaks through him. (2004, p. 392)

In this example, we see how any identity and, in the case of the Pope, any position of authority, is 'displaced from itself' (Wood, 2012, p. 147). Such displacement is what ties the subject to the Real; a self-relating negativity that is not an 'imaginary distance towards symbolic identification', but 'a dimension of self-relating negativity which a priori eludes the domain of vécu, of lived experience' (Žižek, 2000, p. 259). Indeed, what we observe in the comic character is the very performance of a 'gap', which is transposed in the comic character. It is in such instances that 'we cannot say that the subject-actor represents a (comic) character for the spectator-this would reflect the actor's performance of a character in tragedy-'but that the subject-actor appears as that gap through which the character relates to itself, "representing itself" (Zupančič, 2008, p. 35).

Such a 'relating to itself' can be seen in various instances where comic characters 'break the fourth wall'. In fact, 'breaking the fourth wall' is not unique, with the tactic being seen in the comedy series Fleabag (2016-2019). In the series, the lead character, 'Fleabag' (note, we are never given a 'real' human name), frequently glances at, speaks to and acknowledges the camera ('us', the audience). Over the course of the series we learn that this camera-acknowledgment forms part of the character's own psychic estrangement as she comes to terms with the death 
of her best friend and the guilt that she suffers by playing a part in her death. What is significant, however, is that it is in the performance of the comic character -'Fleabag'-that we observe the subject's self-estrangement, as reflected in a similar example from Žižek:

Recall the immortal Lucy from I Love Lucy whose trademark gesture when something surprised her was to bend her neck slightly and cast a direct fixed gaze of surprise into the camera-this was not Lucille Ball, the actress, mockingly addressing the public, but an attitude of self-estrangement that was part of 'Lucy' (as a screen persona) herself. (2006, p. 106, parenthesis removed).

Notably, in the comic performance of Lucy, we do not get Lucille Ball and Lucy, but 'Lucy' as a 'pure difference', as that which separates herself from herself.

Consequently, if we follow the Lacanian contention that the subject is marked by an inherent lack, which, for Žižek (1998), is what constitutes the subject as Real, then, in the case of comedy, it is this lack/'gap' which appears through the character's concrete materiality and which reflects the subject's self-estrangement within a symbolic order that, nevertheless, serves to designate the subject's position (Zupančič, 2008). This endows comedy a level of efficacy which 'exposes the incompleteness of the social order and of the subject who exists within this order' (McGowan, 2014, p. 205).

\section{Conclusion}

The underlying purpose of this paper has been to introduce and apply Zupančič's analysis of comedy and the comic character so as to help highlight comedy's subversive potential. Central to this process is the role of the comedy character, who, in a 'true' comic performance, renders explicit the concrete universal. In doing so, the comic character can serve to avail the self-difference at the heart of the Lacanian subject; a self-difference that the comic character puts to work. For Lacan, the subject is identified 'in the interstice of the "minimal difference," that is, 'the minimal gap between two signifiers' (Žižek, 2004, p. 61); or, in the 'gap' between the enunciated content (what is said) and the position of enunciation (the position from which the content is said) (Black, n.d.). Importantly, this 'minimal difference' ensures that the subject never coincides with itself (Rothenberg, 2010).

Accordingly, it is in this way that, 'A comic character is never fully identified with his role; he always retains the ability to observe himself from outside, "making fun of himself" (Žižek, 2006, p. 107). This observance-portrayed through subtle looks at the camera-suggests a formal significance that reveals not some innate truth, held behind and thus revealed by the comic performance; but, instead, the minimal difference that posits the subject from itself. Žižek adds:

the comic effect proper occurs when, after the act of unveiling, we confront the ridicule and the nullity of the unveiled content: in contrast to the pathetic scene of encountering, behind the veil, the terrifying Thing, too traumatic for our gaze, 
the ultimate comical effect occurs when, after removing the mask, we confront exactly the same face as the one on the mask. This is why the Marx Brothers' 'This man looks like an idiot and acts like an idiot; but this should not deceive youhe is an idiot!' is properly comical: when, instead of a hidden terrifying secret, we encounter the same thing behind the veil as in front of it, this very lack of difference between the two elements confronts us with the 'pure' difference that separates an element from itself. (2006, p. 109)

In comparing this 'lack of difference between two elements' as constitutive of the very 'gap' which marks the subject (Sbriglia \& Žižek, 2020), we can consider how it is this minimal 'pure' difference which avers the Real, or, at least, suggests a way of engaging with the Real through comedy-a way of 'looking awry' (Žižek, 1991). It is along these lines that the 'comic art' and the comic character, 'creates and uses this minimal difference in order to make palpable, or visible, a certain real that otherwise eludes our grasp' (Zupančič, 2003, p. 168). For Zupančič, 'One could go even further and state that, in the comic paradigm, the Real is nothing else but this minimal difference it has no other substance or identity' (2003, p. 168).

As a point of subversion, it is argued here that it is the comic character's performance of this minimal difference that bears a unique significance for the subject; one that echoes its position within the symbolic order. Indeed, while contemporary forms of cynicism, irony and satire seek to distance the audience (and the comic character) from the performed content-a divorcing of the universal from the concrete; exemplified by the concern that we can all make mistakes and that the character on screen is only human, just like us-it is, instead, through 'the immediate coincidence of universality with the character's/actor's singularity' that the very minimal difference in the comic character/actor posits its own self-negativity (Žižek, 2006, p. 107). Thus, comic pleasure, for both the subject and the comic character, emanates from the realisation that the universal fails; that the universal, much like Lacan's big Other, is inconsistent and that such failure is achieved, not by ridiculing the universal, but by comically performing the universal's ridiculousness through the many incongruities of its particular concrete example.

\section{References / Список литературы}

Alonso, P. (2016). Sacha Baron Cohen and Da Ali G Show: A Critique on Identity in Times of Satiric Infotainment. The Journal of Popular Culture, 49(3), 582-603. doi: 10.1111/jpcu.12418

Billig, M. (2001). Humour and Hatred: The Racist Jokes of the Ku Klux Klan. Discourse \& Society, 12(3), 267-289. doi: 10.1177/0957926501012003001

Black, J. (2021). Race, Racism and Political Correctness in Comedy - A Psychoanalytic Exploration. Abingdon, UK: Routledge.

Black, J. (n.d.). On Reflexive Racism: Disavowal, Deferment and the Lacanian Subject. Diacritics. (In Print).

Bonic, N. (2011). Psychoanalysis and comedy: The (im)possibility of changing the socio- symbolic order. S: Journal of the Jan Van Eyck Circle For Lacanian Ideology Critique, 4, 91-108. 
Critchley, S. (2002). On Humour. London, UK: Routledge.

Donougho, M. (2016). Hegelian Comedy. Philosophy \& Rhetoric, 49(2), 196-220. doi: 10.5325/ philrhet.49.2.0196

Flisfeder, M. (2017). Postmodern Theory and Blade Runner. New York, NY: Bloomsbury.

Kottman, P. A. (2008). Slipping on banana peels, tumbling into wells: Philosophy and comedy. Diacritics, 38(4), 3-14.

Ladegaard, J. (2014). Laughing matters: Four Marxist takes on film comedy. In E. Mazierska \& L. Kristensen (Eds.), Marx at the Movies: Revisiting History, Theory and Practice (pp. 102-122). Basingstoke, UK: Palgrave Macmillan.

Ladegaard, J. (2017). The comedy of terrors: Ideology and comedy in Marlowe's Doctor Faustus. Textual Practice, 31(1), 179-195. doi: 10.1080/0950236X.2016.1188141

McGowan, T. (2014). The barriers to a critical comedy. Crisis and Critique, 1(3), 201-221.

McKenna, T. (2015). Art, Literature and Culture from a Marxist Perspective. Basingstoke, UK: Palgrave Macmillan.

Peters, L., \& Becker, S. (2010). Racism in comedy reappraised: Back to Little England? Comedy Studies, 1(2), 191-200. doi: 10.1386/cost.1.2.159_1

Roche, M. W. (2002). Hegel's theory of comedy in the context of Hegelian and modern reflections on comedy. Revue Internationale de Philosophie, 221(3), 411-430.

Rothenberg, M. A. (2010). The Excessive Subject: A New Theory of Social Change. Cambridge, UK: Polity.

Ruda, F. (2016). Abolishing Freedom: A Plea for a Contemporary Use of Fatalism. Lincoln, Neb.: University of Nebraska Press.

Sbriglia, R., \& Zizek, S. (2020). Introduction: Subject Matters. In R. Sbriglia \& S. Zizek (Eds.), Subject Lessons: Hegel, Lacan, and the Future of Materialism (pp. 3-30). Evanston, Ill.: Northwestern University Press.

Weaver, S. (2011). Liquid racism and the ambiguity of Ali G. European Journal of Cultural Studies, 14(3), 249-264. doi: 10.1177/1367549410396004

Wood, K. (2012). Zizek: A Reader's Guide. Chichester, UK: Wiley-Blackwell.

Žižek, S. (1991). Looking Awry: An Introduction to Jacques Lacan Through Popular Culture. Cambridge, MA: MIT Press.

Zizek, S. (1998). Tarrying with the Negative: Kant, Hegel, and the Critique of Ideology. Durham, NC:

Duke University Press.

Žižek, S. (2004). The Structure of Domination Today: A Lacanian View. Studies in East European Thought, 56(4), 383-403. doi: 10.1023/B:SOVI.0000043002.02424.ca

Žižek, S. (2005). The Christian-Hegelian comedy. Retrieved 14 September 2021, from Cabinet website: https://cabinetmagazine.org/issues/17/zizek.php

Žižek, S. (2006). The Parallax View. Cambridge, MA: MIT Press.

Zizek, Slavoj. (2000). The Ticklish Subject: The Absent Centre of Political Ontology. London, UK: Verso.

Zupančič, A. (2003). The Shortest Shadow: Nietzsche's Philosophy of the Two. Cambridge, MA: MIT Press.

Zupančič, A. (2008). The Odd One in: On Comedy. Cambridge, MA: MIT Press. 